\title{
Growing Mediums for Medical Cannabis Production in North America
}

\author{
Reza Nemati ${ }^{1, *}$, Jean-Pierre Fortin ${ }^{2}$, Joseph Craig ${ }^{3}$ and Shaye Donald ${ }^{2}$ \\ 1 The Scotts Canada Company, 771, rue Principale, St-Bonaventure, QC J0C 1C0, Canada \\ 2 Hawthorne Gardening Company, 2468 192nd Street, Units 104-106, Surrey, BC V3Z 3X1, Canada; \\ jpfortin@hawthornegc.com (J.-P.F.); sdonald@hawthornegc.com (S.D.) \\ 3 Independent Researcher, Marysville, OH 43041, USA; craigjoe68@hotmail.com \\ * Correspondence: reza.nemati@scotts.com
}

Citation: Nemati, R.; Fortin, J.-P.;

Craig, J.; Donald, S. Growing

Mediums for Medical Cannabis

Production in North America.

Agronomy 2021, 11, 1366. https:/ /

doi.org/10.3390/agronomy11071366

Academic Editors: William

Carl Fonteno III, Jean-Charles Michel

and Brian Eugene Jackson

Received: 31 May 2021

Accepted: 3 July 2021

Published: 5 July 2021

Publisher's Note: MDPI stays neutral with regard to jurisdictional claims in published maps and institutional affiliations.

Copyright: (c) 2021 by the authors. Licensee MDPI, Basel, Switzerland. This article is an open access article distributed under the terms and conditions of the Creative Commons Attribution (CC BY) license (https:// creativecommons.org/licenses/by/ $4.0 /)$.

\begin{abstract}
The production and use of cannabis for medical purposes has been legalized in Canada and several states in the USA. Due to the historically illegal nature of cannabis, there is very little information available in academic publications about appropriate growing media for growing cannabis. The purpose of this review is to provide an overview of the most commonly used growing media for the production of medical cannabis and to discuss their advantages and disadvantages. Based on current knowledge, there is a general agreement on the properties of a suitable growing medium within the cannabis industry. However, there is little consensus among growers on the best growing medium to grow cannabis. Different categories of growing media are widely used in North America. In this review, we classified them into several main categories principally based on the type of material used in their composition and the growth stages of the plant. The main categories include: coir-based, peat-based, rockwool, phenolic foam, and living soil. It is not easy to suggest the best growing medium for cannabis production. Each category of growing medium has its strengths and weaknesses. Overall, it seems that coir-based products are the intermediate substrates showing more advantages and less weakness; however, choosing any of these categories depends a lot on the growing technique and production system. Future research should focus on determining the optimal level of growing media properties to produce high yielding medical cannabis with the desired quality.
\end{abstract}

Keywords: Cannabis; growing media; coir-based; rockwool; phenolic foam; peat-based; living soil

\section{Introduction}

Since October 2019, several hundred licensed medical cannabis producers (LP) have been approved by the Government of Canada [1]. At the time of writing, the production of legal medical cannabis has been approved in 35 states in the United States plus Washington, D.C.; however, it is still federally illegal [2]. Growing Cannabis (Cannabis sativa L.) has been illegal for many years [3] resulting in very little information in scientific research about cannabis production and appropriate growing media for this plant [4]. During these years, there has been very limited science to guide this industry [3]. LP principally uses two sources of growing media. Soilless media like peat-based, coir-based, and rockwool are common, while a small portion use true hydroponic systems such as deep water culture and aeroponic systems [4,5].

Medical cannabis is typically grown in controlled environments where LPs steer the crops through various cultural practices. Managing soil moisture and air contents to drive growth while maintaining healthy plants is critical. An appropriate high quality growing media must have the following properties: consistent with well-balanced physical and chemical properties, fast draining with high saturated hydraulic conductivity (Ksat), maintaining a moderate water content between irrigations, and ample pore space occupied with air to reduce the risk of root pathogens like Pythium $[4,6]$. Based on some research, cannabis 
production needs a high porosity substrate which can increase dry floral weight and THC concentration [4,7]. Cannabis roots prefer light and well aerated substrates [8]. Roots that grow in a well aerated substrate are stronger and develop more lateral branches [9]. From a chemical property point of view, a good soilless mix is capable of supporting a high nutrient content as well as the ability to be fertilized often, because the LPs need to add the right amounts of nutrients and at the right time. The LPs also need to have a substrate free of weeds and pathogens [5]. In addition, substrate selection must be made according to irrigation and fertilization strategies.

In terms of growth and development, cannabis plants have three main stages: propagation (germination and seedling), vegetative, and flowering stages $[10,11]$. Each stage presents its own unique challenges in terms of growing media.

The propagation growing media can be classified into several main categories principally based on the type of material used in their composition. These categories include: rockwool cubes, preformed peat media based, preformed and stabilized media (i.e., peatbased or coir-based), deep water clone sprouter and plug trays. A propagation soilless mix must be moist but well aerated to enhance root initiation and rapid development of young roots [12]. Propagation mixes have low fertilizer starter charge. The growing mediums for propagation are usually composed of fine components to allow filling small containers or propagation units. Despite their fineness, components need to be clean (i.e., with limited quantity of dust) to allow roots to easily penetrate and rapidly establish. They are designed for small size containers and to maintain optimal moisture for uniform germination and rapid rooting [13].

Growing media for vegetative and flowering stages of cannabis can be classified into several categories depending on the type of material used in their composition $[10,11,14]$. The main categories are: peat-based mixes, coir-based mixes, coir blocks, and preformed rockwool and foams $[5,14]$. Growing media used to grow cannabis during the vegetative stage are not, in general, different from those used through the flowering stage. It is a general habit to use the same media as the one used to finish the crop. Therefore, it is not the growing media that differs at the vegetative stage but rather the size of the container. It is common to plant clones directly into the final container ( $<3$ gallons), for plants that will reach a height of $150 \mathrm{~cm}$. For production of taller plants (>3 gallons), clones are usually planted into a smaller pot (1 gallon) for plant establishment as an intermediate stage before transplanting them into the final container. This technique is like the nursery industry, where a liner is rooted in a smaller container before finishing the plant into a larger container. This intermediate step is also used for outdoor production of medical cannabis since the plants are usually much larger.

Any change in the container geometry (height and width) can considerably affect the physical properties of growing media. As an example, the impact of container height on physical properties and water volume per irrigation in a mix is presented in Table 1. Based on this data, air-filled porosity increases with the height of the substrate in the container. Inversely, container capacity (CC), easy available water (EAW), available water (AW) and the amount of water that can be added without leaching decreases with the height of the substrate in the containers. In fact, in a saturated soilless mix, once free drainage happens and equilibrium is reached, the bottom end of the mix remains at saturation (perched water), where the matrix potential is equal to zero [15]. In this case, the proportion of air to water in soil profile increases as a function of distance from container bottom. Therefore, the average moisture content of the soil profile decreases by increasing the height of the mix in the container. The grower needs to adopt the irrigation strategy based on this dynamic moisture content in order to prevent overwatering (leaching) and underwatering (excessive drying). This is an important point especially in organic production systems where the leaching control is essential to manage the limited quantity of nutrients. Bilderback and Fonteno [16] reported that the air and water holding capacities of a growing medium vary depending on the geometry of the container (depth and width) and not just depending on the growing medium. They found that the same growing media in different container sizes 
can provide various levels of air and water to the plants. Therefore, care must be taken to select the appropriate irrigation practice to maintain adequate ratio of air to water in the growing media profile.

Table 1. Physical properties of a peat-based mix as a function of substrate height.

\begin{tabular}{cccccc}
\hline & \multicolumn{5}{c}{ Height of Substrate } \\
\cline { 2 - 6 } & $\mathbf{1 5} \mathbf{~ c m}$ & $\mathbf{2 5} \mathbf{~ c m}$ & $\mathbf{3 0} \mathbf{~ c m}$ & $\mathbf{3 5} \mathbf{~ c m ~}$ & $\mathbf{4 2} \mathbf{~ c m ~}$ \\
\hline Container Capacity (\%) & 49 & 45 & 42 & 39 & 36 \\
Air-Filled porosity (\%) & 29 & 33 & 36 & 39 & 42 \\
Easy Available Water (\%) & 21 & 16 & 13 & 10 & 8 \\
Available Water (\%) & 23 & 18 & 15 & 13 & 9 \\
Irrigation volume for 10-L mix (mL) & 2300 & 1800 & 1500 & 1300 & 900 \\
\hline
\end{tabular}

1 to bring volumetric moisture content from $-10 \mathrm{kPa}$ to Container Capacity.

From a nutritional point of view, fertilization must also be adjusted during the cannabis production [17]. Plants are small at planting and do not pull out large volumes of water but have large nutrient requirements. The fertilizer charge must be adjusted to plant needs despite the small volume of water used during the first irrigations. The purpose of this document is to review the physical and chemical properties of the most commonly used growing media for the production of medical cannabis in North America and to discuss their advantages and disadvantages.

\section{Main Categories}

\subsection{Coir Based}

Coir based growing media is one of the most widely used substrates for the production of medicinal cannabis in North America [14]. The most common growing media for this category are: pure coir (loose), coir and perlite (loose), expandable coir blocks (various formulation of coir pith, fiber, and husk chips), preformed coir (blocks and pyramidal structures), grow bags and grow slabs.

Considered as a residue of the coconut industry, it is now widely used for the production of horticulture crops [18]. The coir materials are available in various particle sizes ranging from fine particles, also called coir fiber or dust, to large fibrous material $(2 \mathrm{~cm}$ to $10 \mathrm{~cm}$ long) of amorphous shapes and to chunks or various sizes. The main characteristic of coir materials is its hydrophilic property [19] and having a tough structure. Coir has an excellent wettability and can rewet easily [20,21], thus reducing the need for wetting agents. It also has a slow breakdown rate and therefore does not shrink during the growing production cycle. The aeration and drainage are usually high in coir products although it depends on their particle size distribution [20,22]. Coir material usually holds a high volume of water [21] because of its ability to absorb water. It has also a high aeration because of its particle size and structure. Coir products are seen as an alternative to rockwool products and an intermediate solution compared with peat-based products [20,22,23]. Indeed, the aeration and the drainage are high enough for some products to manage irrigation in a similar way compared with rockwool. It is possible to practice several consecutive irrigation events and achieve a leaching point on a per event or day basis in a way similar to rockwool. Despite these similarities, there is a distinct difference between rockwool and coir production in terms of sustainability. Specifically, rockwool is not easily recyclable or reusable after use whereas coconut coir production is relatively sustainable.

Although these attributes make coir products popular, the material available on the market is variable and may cause some problems to inexperienced users [24]. Particle size may vary from fine dust (1 to $4 \mathrm{~mm}$ ) to large chunks, $1-4 \mathrm{~cm}$ in diameter. That makes a large array of products with variable physical properties available to users. The coir product can be compressed to a 5:1 ratio on a volume basis for example. Compressed products expand and gain their original volume easily when watered (15-19 L of water to hydrate a $5 \mathrm{~kg}$ block of coco coir, based on HortGrow [25]). That property allows coir 
products to be offered in various sizes and shapes and reduce the volume when stored. Coconut pith, fiber, chunks and blends are offered as compressed bricks, slabs and various pre-shaped stabilized products. Stabilized products are available as rooting cubes, grow cubes of various sizes and shapes. Beside regular cubes, the pyramid grow unit is one the most unusual stabilized products found on the market.

Coir may have a high salts level if it is not washed or buffered. However, salts are relatively soluble and leachable in coir. Unwashed and unbuffered coir is usually rich in sodium, potassium and chloride and therefore may cause a risk of calcium and magnesium deficiency during a lag period. Coir also has a fairly high cation exchange capacity and therefore can help retain nutrients. The chemical structure and the high internal porosity of the fiber contribute to its high exchange capacity (Figure 1). K, Na and $\mathrm{Cl}$ can be present in amounts detrimental to crop developments [21]. These elements must be mitigated or replaced with more beneficial ones [20,24]. A common manufacturer's technique is to wash coir with fresh water to remove excess salts [26]. The washing techniques are various such as leaving bulk material to open rainfall. The results are variable and users should test their products before use. A second well known technique in the industry is to use certain mineral salts, most commonly calcium salts, during washing to force the exchange of excess elements with more beneficial elements [26]. The resulting product is said to be "buffered". Buffering is a chemical process by which the excess sodium and potassium bound to the coir are replaced by calcium to help prevent calcium and magnesium deficiency during the growth cycle. A period of time is allowed for the exchange to take place, then leached and dried in the open air. The efficacy of buffering is variable among manufacturers and depends on the volume of water for leaching, the buffering salts used, and the time period allowed for cation exchange.

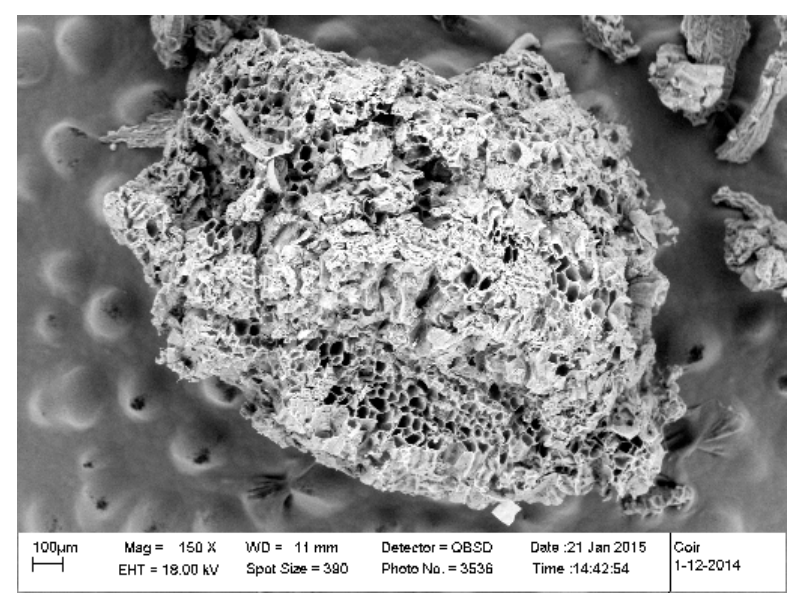

Figure 1. Scanning electron microscopic view of a coir particle.

Irrigation practices in the cannabis industry are widely varied. This is largely due to the clandestine background of cannabis production limiting scientifically led investigation into the best practices for cannabis production, as previously mentioned. One major factor relating to the frequency and duration of irrigation events is the volume of substrate that the plants are growing in, as well as the growing style employed. As an example, a grower may only have a large irrigation event once every 2 days because they are growing in a very large pot. Another grower may have a small substrate volume, requiring many irrigation events per day.

Unlike other crops grown in high intensity container based production, there are no agreed upon standards currently for the irrigation strategies in cannabis. This is beginning to change gradually, with a notable shift towards higher frequency irrigation strategies with a smaller volume of substrate. This is more in-line with traditionally grown crops such as greenhouse tomato, cucumber and pepper which have been grown in progressively smaller 
substrate volumes to reduce cost of production, as well as increase the controllability of the moisture content of the root zone.

One notable property of coir-based growing media is their high aeration [20,22], as mentioned above. This helps to maximize the root zone of the crop, increasing root growth, which leads to increased water and nutrient uptake throughout the lifecycle of the crop. Cannabis is notoriously susceptible to root disease, and a lack of oxygen in the root zone is a strong contributing factor for the infection and spread of root pathogens. Coconut coir has a reputation for being difficult to overwater, and is associated with a reduced instance of disease. This has benefits for hobbyists and commercial growers alike. This, among the properties discussed has led to the increased adoption of coir-based growing media into the cannabis industry.

\subsection{Rockwool}

Rockwool is made from basalt rocks or other minerals which are liquefied at high temperature and then spun into fibers [27]. Rockwool is another one of the soilless options for growing cannabis. It is considered to be an appropriate substrate due to its capabilities to provide moderate to good aeration [21] and possessing excellent water holding capacity [5]. Rockwool is available in multiple sizes and shapes for various applications: blocks, cubes and slabs [28-30]. The use of rockwool as a growing medium has several advantages. It is a lightweight substrate with a bulk density of about 50-100 g/L [31] and is easy to handle and to use. Rockwool is homogeneous, consistent and durable which means it does not readily break down and it keeps relatively consistent properties. Rockwool is usually free of phytopathogenic microorganisms due to use of heat to produce rockwool which renders it sterile and safe for growing plants. Because of this heat, rockwool is unlikely to contain naturally occurring beneficial microbial populations when first planted out. However, microbial life does develop in rockwool during the growth cycle of plants. Rockwool is considered as an inert material which means it neither reacts to nor changes the nutrient balance of the applied solution. It has low nutrient retention capacity (CEC about zero).

Rockwool exhibits 91 to $95 \%$ total porosity that can be occupied with water when saturated or with air when dried [12,21]. It can hold more nutrient solution and air than any other growing medium. This air space makes oxygen, water and nutriment solution easily accessible to plant roots. Rockwool has a high air capacity and high ratio of easily available water (EAW). Rockwool has very low unavailable water (bounded water) and it drains well. It also has a uniform wetting. It promotes root growth, and provides even drainage.

On the contrary, the use of rockwool may face many challenges. Rockwool is not environmentally friendly [21]. The same quality that makes it durable also makes it an environmental nuisance. Rockwool based growing mediums may require the use of a wetting agent to reduce their hydrophobicity. However, wetting agents can be washed out over time. Rockwool may dry too fast at the end of the season. Due to its zero CEC, all of the fertilizers (nutrients) can be easily leached from it. Rockwool typically has a high $\mathrm{pH}$ and nutrient solutions must be adjusted to accommodate for that factor. It is also susceptible to $\mathrm{pH}$ shift which creates the need to continuously monitor the $\mathrm{pH}$ levels. Although rockwool has a high water retention capacity, it has a restricted root environment and a low buffering capacity for water, $\mathrm{pH}$ and nutrients [29,31]. The water flow to plant roots may be hindered, even when the water content is apparently high [29]. Because rockwool stays so moist, algae growth is common. If the green algae turns black and slimy (decaying) it can harbor bacteria or viruses that can affect the plants. The algae developed on rockwool can attract fungus gnats as well as hinder water penetration from drip emitters.

As mentioned above, the low bulk density and high water retention of rockwool make it a suitable growing substrate for crop production. Because water content decreases so sharply as water tension increases, the ideal irrigation strategy for rockwool is to keep it nearly saturated throughout the day $[29,31]$. This is achieved through high frequency, and 
low volume irrigation [12]. In the peak of crop growth, a crop may require up to or over 20 irrigation events in one day for a 6-in cube in order to keep up with crop demand.

Low volume irrigation events are the key to rockwool irrigation. This prevents excessive waste in the form of leachate, while keeping the block and plant in the 'easily available water' zone (Figure 2 and Table 2). Growers commonly irrigate by using a leachate fraction target to guide the irrigation frequency, although there is more focus on sensor technology which can accurately determine the volumetric water content or water potential to guide irrigation decisions. Traditionally, leachate fraction targets in greenhouse grown crops is as high as $20-30 \%$ in rockwool. This is being reduced with the advent and adoption of accurate sensing technology.

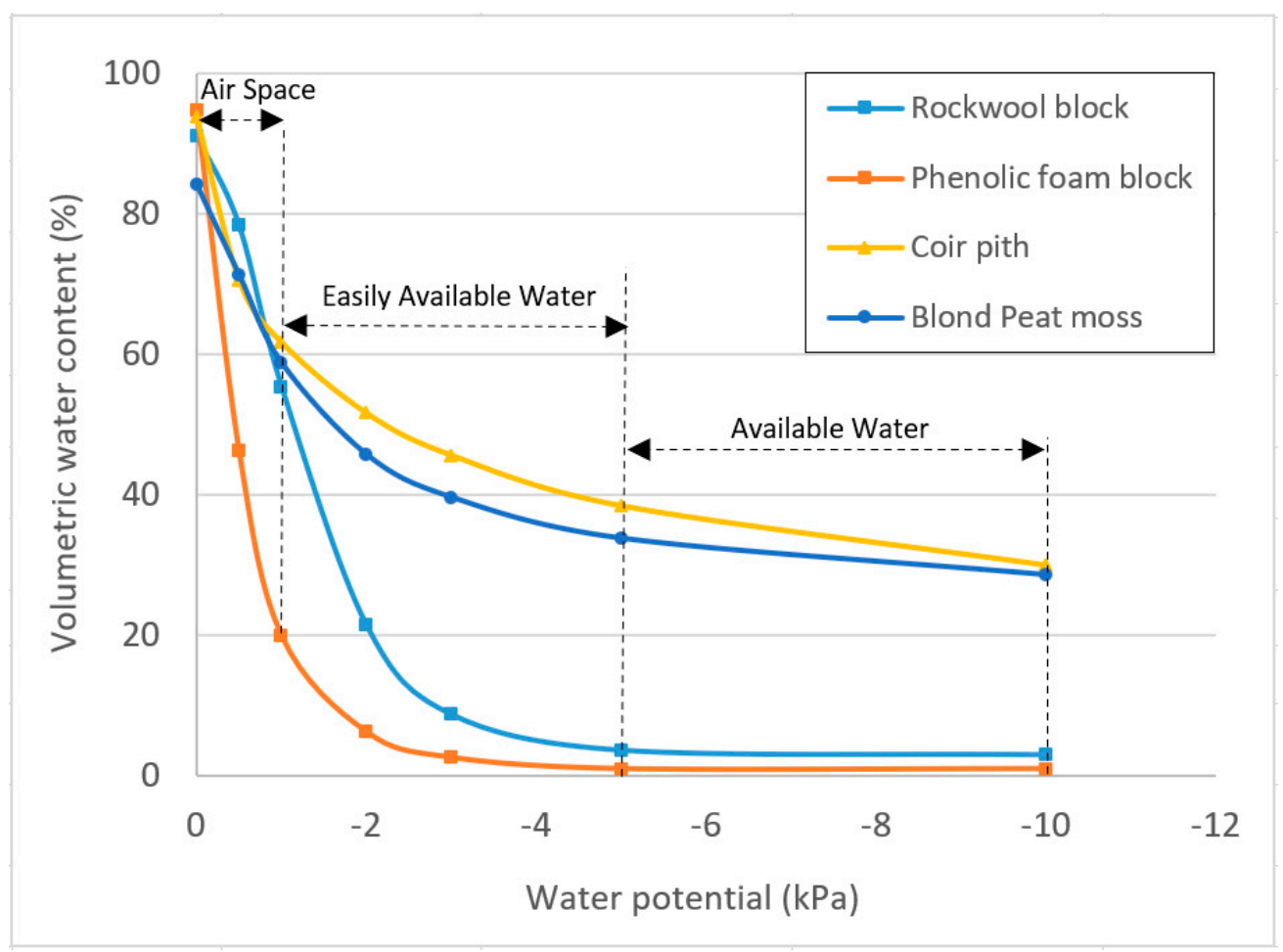

Figure 2. Moisture retention curves for selected soilless growing media.

Table 2. Physical properties of the selected materials adjusted for a height of $14 \mathrm{~cm}$.

\begin{tabular}{ccccccccc}
\hline $\begin{array}{c}\text { Growing Medium } \\
\text { Types }\end{array}$ & $\begin{array}{c}\text { TP } \\
\mathbf{( \% )}\end{array}$ & $\begin{array}{c}\text { CC } \\
\mathbf{( \% )}\end{array}$ & $\begin{array}{c}\text { AS } \\
\mathbf{( \% )}\end{array}$ & $\begin{array}{c}\text { EAW } \\
\mathbf{( \% )}\end{array}$ & $\begin{array}{c}\text { AW } \\
\mathbf{( \% )}\end{array}$ & $\begin{array}{c}\text { TBW } \\
\mathbf{( \% )}\end{array}$ & $\begin{array}{r}\text { Ksat } \\
(\mathbf{c m} / \mathbf{s})\end{array}$ & $\begin{array}{c}\text { DBD } \\
(\mathbf{g} / \mathbf{L})\end{array}$ \\
\hline Rockwool block & $91-95$ & $65-71$ & $20-24$ & $61-68$ & $62-69$ & $1-3$ & $\mathrm{EH}$ & $50-100$ \\
Phenolic foam block & $92-96$ & $35-44$ & $52-66$ & $28-42$ & $28-42$ & $1-2$ & EH & $15-25$ \\
Coir pith & $88-94$ & $60-69$ & $24-34$ & $22-30$ & $30-38$ & $25-35$ & $0.04-0.15$ & $65-75$ \\
Blond peat moss & $84-90$ & $65-74$ & $10-20$ & $29-36$ & $35-43$ & $27-34$ & $0.01-0.04$ & $55-75$ \\
\hline
\end{tabular}

TP: total porosity, CC: container capacity, AS: air space, EAW: easily available water, AW: available water, TBW: tightly bound water, Ksat: saturated hydraulic conductivity, DBD: dry bulk density, EH: extremely high (unmeasurable).

Another reason for high frequency irrigation is to prevent the block from fully drying out. As mentioned, rockwool is hydrophobic when dry. Once a rockwool cube is sufficiently dry, it becomes very difficult to rewet by drip irrigation alone. Some growers will initiate an irrigation event overnight to prevent excessive drying and channeling from occurring.

Low flow drip emitters are a necessity for rockwool irrigation. This is because 'channeling' is observed if flow rates are too high (above $1.0 \mathrm{GPH}$ is commonly used as a benchmark). This channeling effect results from a heavy volume of water 'pushing' its way through the media, creating a channel that allows the water to freely drain out of the 
bottom of the rockwool without wetting the substrate. By slowing the flow rate, it allows time for capillary action to draw the nutrient solution laterally throughout the block.

Crop steering is a method of irrigation that pushes a crop towards either 'generative' or 'vegetative' growth. Irrigation strategies are a common method for reinforcing other signals that can 'steer' a crop. Rockwool is a particularly responsive media for this use, although it is possible in any media type. As stated above, rockwool's properties result in a very sharp decrease in water content as moisture tension increases (Figure 2). This makes it easier to achieve a crop steering effect without impacting photosynthesis. A common strategy when moving from 'vegetative' to 'generative' growth is to double the irrigation volume per event, while cutting the total number of irrigation events in half. Effectively, the leachate fraction and total volume will be the same in both cases, but the altered irrigation strategy is enough to elicit a minor drought stress response without impacting photosynthesis by allowing the plant to reach a lower volumetric water content between irrigation events.

\subsection{Phenolic Foam}

Phenolic foam (PF) is another soilless option for growing cannabis. Phenolic foam is a relatively new soilless substrate that is generally presented as an alternative to rockwool [23]. It has a range of configurations and sizes for propagation and growing. It is a sterile substrate which allows for a clean and pathogen free start. PF is homogeneous and consistent; however, the material is more fragile than rockwool when handling. Despite its fragility, phenolic foam cells are stable and are able to maintain the original air space after continual waterings. Compared to rockwool, PF shows even a sharper decrease in volumetric water content as moisture tension increases (Figure 2). This sharp drop of water holding capacity is the main reason for which the phenolic foams are restricted in height (generally $<10 \mathrm{~cm}$ in height). Due to its high drainage and air porosity (Table 2), PF is a suitable medium for the crops like cannabis. Phenolic foam is an extremely lightweight substrate with a bulk density of about 15-25 g/L. PF has no important cation exchange capacity (CEC) or buffering capacity which means it neither reacts to nor changes the nutrient balance in solution. PF cells are easy to handle and to use. As opposed to rockwool, there is no need for protective gear or clothing when handling PF.

Excellent aeration and moderate to low water holding capacity (Table 2) are the features of this type of growing media [23,32]. The PF based media maintain a high ratio of air to water (Figure 2 and Table 2) even after a heavy watering due to its higher drainage rate which promotes root development. The superior drainage helps to keep its top surface drier, helping to limit the growth and development of algae [32]. PF media has the ability to quickly respond to fluctuations in the plant's rooting environment. PF is usually non-biodegradable and therefore can remain as waste in the environment.

\subsection{Peat Based}

In terms of popularity, peat-based growing media come after Coir and rockwool. Peat is generally harvested from Canadian sphagnum peat bogs and shipped to the Southern regions. There are also other sources of peat moss that are imported from East European countries namely, Scandinavian and Baltics [33]. The latter peat mosses are mainly used for horticulture, but they do not represent a large part of the North American market.

Canadian bogs are populated with several sphagnum species, the most common being Sphagnum magellanicum (now renamed as Sphagnum medium and Sphagnum divinum), Sphagnum fuscum, Sphagnum rubellum and Sphagnum angustifolium [34]. The species may vary from a bog to another as well from one region to another [34,35]. The incorporation of coarse peat fibers or the mixture of fibrous and chunky materials extracted from bog to the peat moss can be used to increase peat resistance to shrinkage and to compaction and hence helps to maintain the physical properties. Peat moss has a high buffering capacity for water, $\mathrm{pH}$ and nutrients. It is acidic, hydrophobic and low in nutrients [24]. Therefore, additives need to be incorporated to make it suitable for growing plants [22]. 
Acid neutralizing agents (dolomitic or calcitic limestone), wetting agents and nutrient charge are incorporated to various levels depending on the manufacturer. Peat has a spongy structure without lignified fiber (Figure 3). Lignified fibrous material may originate from other species growing on the peat bog if any. Like coir materials, peat moss shows clearly higher volumetric water content than rockwool and phenolic foam as moisture tension increases (Figure 2, Table 2). As shown in Table 2, the blond peat moss shows relatively a lower total porosity $(84-90 \%)$ and air space $(10-20 \%)$ and an intermediate level of container capacity (65-74\%), easy available water (29-36\%), available water (35-43\%) and tightly bound water (27-34\%), compared to all other materials.

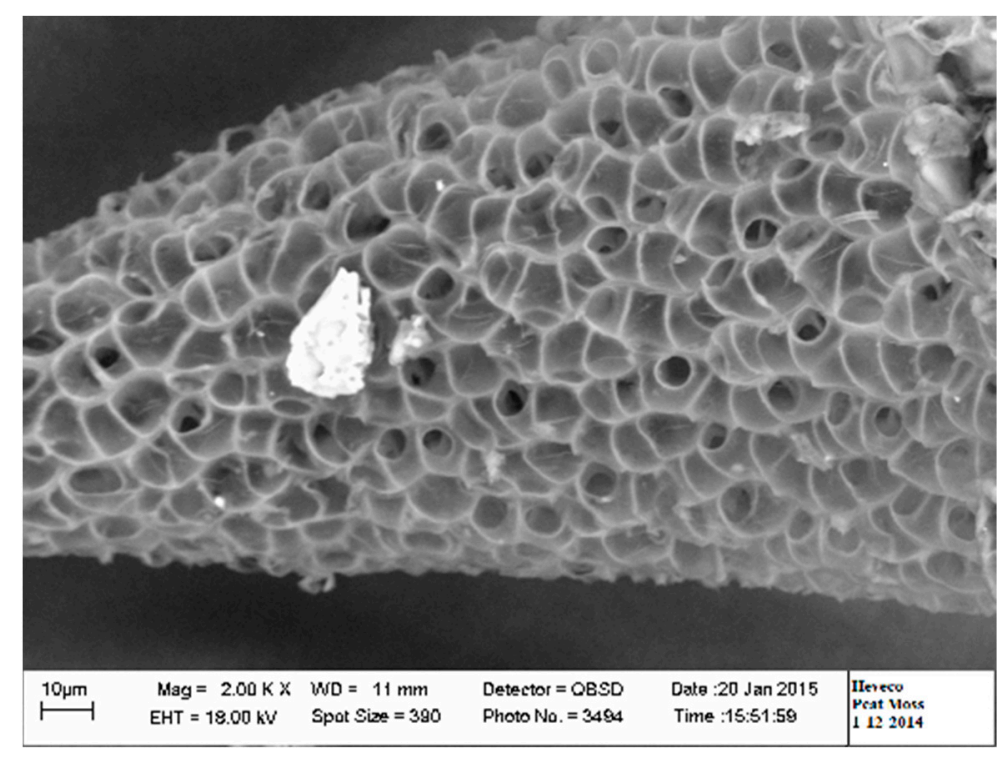

Figure 3. Scanning electron microscopic view of a peat moss particle.

Sphagnum peat moss is usually mixed with other components to accentuate the physical characteristics of the growing media [33]. The incorporation of other components helps peat to maintain a good structure. Other reasons to incorporate other components are to increase aeration, to make the growing media less hydrophobic [36], to improve cation exchange capacity, to contribute to the nutrients charge, and to produce a drier mix. A component can be used alone or in combination with others. Table 3 lists the most common components used in peat-based growing media for growing medicinal cannabis.

Table 3. Most common components used in combination with peat-based growing media.

\begin{tabular}{ccc}
\hline Components & $\begin{array}{c}\text { Typical Volume } \\
\text { Contribution (\%) }\end{array}$ & $\begin{array}{c}\text { Typical Physical and/or Chemical } \\
\text { Contributions }\end{array}$ \\
\hline Perlite & $10-35$ & Aeration, physical stability, drier mix \\
Vermiculite & $5-15$ & Aeration, increase wettability and CEC \\
Wood fiber & $20-40$ & Aeration and better gas exchange \\
Coir pith & $5-25$ & Aeration, better wettability \\
Coir chunks & $5-25$ & Aeration, physical stability \\
Processed bark & $5-30$ & Aeration, physical stability \\
Compost & $0-10$ & Nutrient charge, biodiversity \\
Calcined clay & $0-5$ & Increase CEC and increase rate of mineral \\
Earth minerals (sand, & $0-5$ & Increase rate of mineral \\
azomite and volcanic rock) & &
\end{tabular}

\subsection{Living Soils}

The living soil category includes a vast array of growing media formulations. There are no standards that define living soil for the cultivation of medicinal cannabis. There are 
numerous soil manufacturers or growers that blend their own growing media and consider them as living soil. Living soil can be as simple as incorporating a microbial inoculant into a growing media but it can be much more complex [37]. The living soil matrix must support microbial populations, soil flora and evidently the plant growth [37]. The combination of volume-based ingredients and additives must provide the necessary physical and chemical conditions for optimal growth and development of cannabis. The soil composition must promote microbial activity and diversity since it is the basis of the mineralization, and also favor beneficial species to counterpart adaphic root diseases [37,38]. Biodiversity is important in living soil to maintain a balance between mineralization, plant protection and biostimulation. David Bernard Perron from The Green Organic Dutchman (TGOD) considers living soils as bioreactors. The basic components of living soils are peat moss, coir pith, coir chunks, naturally aged bark, wood fiber, composts and natural additives. A variety of inoculants can also be used in living soils: compost, bacterial inoculants, mycorrhizae and actinomyces to name a few. LPs that grow in living soils face several challenges: (1) to constitute a porous growing media with the optimal physical properties, (2) to provide the ample nutrition to support a complete growth cycle, and (3) to manage irrigation to prevent leaching of essential elements.

First challenge is related to the physical properties in living soil. In conventional culture (non-living soil), the cannabis producers prefer to grow in fast draining, coarse, and well aerated media. The use of this type of soilless media ensures a proper leaching of excess nutrients from the soil. In many cases, cannabis growing practices involve a high volume of leaching either per irrigation or per day. Therefore, it is common to frequently replace a part of the soil solution with a fresh fertilizer solution. This practice guarantees the grower to maintain a desired soil solution composition and soluble salt concentration. As opposed to conventional soilless media, in living soil some of the physical properties like the storage and transmission of water and air can be compromised due to limited choice of components as well as the use of fine textured materials like compost and additives. Moreover, the structure of the living soil can be rapidly modified under the activity of the microorganisms and the flora.

Nutrition availability is the second challenge in the living soil. Cannabis is a species that grows very fast and needs nutrients to rapidly become available in high concentrations. The organic greenhouse vegetable industry has overcome this challenge by establishing a microflora that speeds up the mineralization cycle [39]. However, cannabis is often grown over a shorter period of time compared with cucumber ( 4 months), and peppers and tomatoes (10 to 11 months). A typical growth period for cannabis is about 11 to 13 weeks that consist of 3 weeks under a vegetative photoperiod and 8 to 10 weeks under a generative photoperiod. In some cases, the growth cycle can be as short as 8 to 9 weeks. LPs experience a challenge to establish an active nutrition system in the living soil in a short period of time. They usually overcharge the growing media with more than necessary amounts of natural fertilizers and additives to ensure the availability of the elements needed up to the maturity of the crop. The biggest downside to living soil is that plants tend to grow a little slower than with other soilless media [17].

Irrigation strategy is the third challenge to consider in the living soil. The amount of water per irrigation event must be controlled to ensure an optimal rate of air to water ratio for plants and soil organisms. Ultimately, it is important to better define living soils since they are gaining in popularity for the cultivation of cannabis and numerous other crops. Living soil is a particular growing system compared with conventional growing media and will necessitate setting the standards.

\section{Conclusions}

It seems that there is a general agreement on the properties of a suitable growing medium within the cannabis industry. In general, LPs look for a growing media with the following properties: high porosity, fast draining, maintains moderate water content between irrigations, capable of fast dry downs to reduce the risk of root pathogens, 
well-balanced physical and chemical properties, high consistency and free of weeds and pathogens. However, there is little consensus among LPs on the best growing medium for cannabis production. Different categories of growing media are widely used in North America. The most common ones are: coir-based, peat-based, rockwool, phenolic foam and living soil. Each category has its strengths and weaknesses.

Although peat-based growing media are widely used, they are less popular than coir-based and rockwool. Peat based substrates show greater buffering capacity for water, $\mathrm{pH}$ and nutrients compared to rockwool and phenolic foams. Inversely, peat-based substrates usually show lower aeration (Table 2) and gas exchange rate compared to other categories mainly due to their particle size and shrinkage. To resolve these issues, the incorporation of aggregates (e.g., perlite) or fibrous materials (e.g., peat chunks, wood fiber) are typical options to improve the physical properties. In addition, peat-based substrates are sometimes less consistent principally due to variation in peat moss quality.

Rockwool and phenolic foams exhibit excellent physical properties compared to other categories. They usually have high ratios of easy available water and air space (Table 2). However, these parameters can be drastically changed with the geometry of substrate (height and width). Therefore, growers need to adopt an irrigation strategy that provides optimal water, air and nutrients to the cannabis roots to produce healthy high yielding plants. Rockwool and phenolic foams are inert, homogeneous, consistent, and free of phytopathogenic microorganisms. In addition, they maintain a high ratio of air to water even after a heavy watering due to their higher drainage. Despite these advantages, the use of rockwool and phenolic foams can lead to some environmental issues. Specifically, because growing in these materials usually generates a high volume of leaching which contains different forms of pollutants (fertilizers and pesticides). Furthermore, rockwool and phenolic foams are not easily recyclable, or reusable after the use.

Because of the sharp decrease in volumetric water content $(\theta \mathrm{v})$ of rockwool and phenolic as water tension increases (Figure 2), the ideal irrigation strategy is to keep $\theta \mathrm{v}$ near to the container capacity through frequent irrigation events. This can be easily achieved through the use of automated irrigation systems. However, our survey shows that most LPs in North America do not have such a system at the time of writing. Indeed, there is a need to use soil sensors and automatic irrigation systems to manage irrigation appropriately in rockwool and phenolic foams and to prevent excessive leaching from these media. The use of such systems can lead to an improvement in the productivity and quality characteristics of the cannabis crop and also to reduce the environmental risks associated with leaching.

Coir based products are the intermediate substrates situated between regular growing media and rockwool. Coir based products usually show better physical properties (aeration, Ksat and wettability) than peat-based products (Table 2). They also tend to be more flexible to irrigation management and can be easily adopted to low or high frequency irrigation strategies. Coir based products have mostly higher buffering capacity for water, $\mathrm{pH}$ and nutrients compared to rockwool. The main weaknesses of coir products are related to higher variation in chemical properties (salt level, concentrations of $\mathrm{Na}, \mathrm{K}$ and $\mathrm{Cl}$, and buffering) and inconsistency in particle size. Growing media consistency is important for LPs because they aim to achieve consistent product and yields. When switching from rockwool or phenolic foams to coir-based substrates, there is a need to adjust the irrigation strategy because the water dynamic is different within these materials.

There is also a tendency in the cannabis industry toward growing in living soil in which biodiversity is important to maintain a balance between mineralization, plant protection and biostimulation. Despite their popularity, growing in living soil faces several challenges related to limited choices of sustainable raw materials with the desired physical properties, providing the optimal rates of nutrients to complete successfully a growth cycle, and limiting leaching of essential elements from living soil.

It is not easy to suggest what is the best growing medium for cannabis production. Each category of growing medium has its strengths and weaknesses. Many factors have to 
be taken into account when selecting a growing substrate. Overall, it seems that coir-based products are the intermediate substrates showing more advantages and less weakness; however, choosing any of these categories depends a lot on the growing technique and production system. At the time of writing, the growing technique and the production system are mainly based on the type of production (indoor vs outdoor) and the size of the plants to be grown.

Author Contributions: Conceptualization, R.N., J.-P.F., and J.C.; methodology, R.N., J.-P.F., and J.C.; software, R.N.; validation, R.N., J.-P.F., and J.C.; formal analysis, R.N.; investigation, R.N., J.-P.F., and J.C.; resources, R.N.; data curation, R.N., and J.-P.F.; writing-original draft preparation, R.N., J.-P.F., J.C. and S.D.; writing-review and editing, R.N., and J.C.; visualization, R.N.; supervision, R.N.; project administration, R.N., and J.C.; funding acquisition, R.N., and J.C. All authors have read and agreed to the published version of the manuscript.

Funding: This research received no external funding. The APC was funded by Scotts Canada Company.

Data Availability Statement: Not applicable.

Acknowledgments: The authors gratefully acknowledge the financial support of Scotts Canada Company, Saint-Bonaventure, Quebec, Canada and Hawthorne Gardening Company, Surrey, British Columbia, Canada. The authors thank David Bernard Perron from The Green Organic Dutchman for discussions on living soil, and Deron Caplan from Flowr Corporation and Tyson Jennett from Hawthorne for discussions on Soilless media used in the cannabis industry.

Conflicts of Interest: The funders had no role in the design of the study; in the collection, analyses, or interpretation of data; in the writing of the manuscript, or in the decision to publish the results.

\section{References}

1. Health Canada. Licensed Cultivators, Processors and Sellers of Cannabis under the Cannabis Act. Available online: https://www.canada.ca/en/health-canada/services/drugs-medication/cannabis/industry-licensees-applicants/licensedcultivators-processors-sellers.html (accessed on 10 October 2019).

2. Rense, S. Here Are All the States That Have Legalized Weed in the U.S. Esquire. Available online: https://www.esquire.com/ lifestyle/a21719186/all-states-that-legalized-weed-in-us/ (accessed on 23 April 2021).

3. University of Guelph. North American First: U of G Researchers Publish Scientific Study on Cannabis Production. Available online: https:/ / news.uoguelph.ca/2017/10/north-american-first-u-of-g-researchers-publish-scientific-study-on-cannabisproduction/ (accessed on 24 April 2021).

4. Caplan, D.; Dixon, M.; Zheng, Y. Coir-based growing substrates for indoor cannabis production. Acta Hort. 2019, $1266,55-61$. [CrossRef]

5. Williams, P. 3 Tips for Selecting Growing Media for Cannabis. Greenhouse Management. Available online: https://www. greenhousemag.com/article/production-3-tips-for-selecting-growing-media-for-cannabis/ (accessed on 24 April 2021).

6. Zheng, Y.; Wang, L.; Dixon, M. An upper limit for elevated root zone dissolved oxygen concentration for tomato. Sci. Hortic. (Amst.) 2007, 113, 162-165. [CrossRef]

7. Caplan, D.; Dixon, M.; Zheng, Y. Optimal rate of organic fertilizer during the flowering stage for cannabis grown in two coir-based substrates. HortScience 2017, 52, 1796-1803. [CrossRef]

8. Jasminka. What's the Best Soil for Growing Autoflowering Cannabis Strains? Dinafem Seeds. Available online: https://www. dinafem.org/en/blog/best-soil-growing-autoflowering-cannabis/ (accessed on 7 February 2021).

9. Nkongolo, V.K.N. Tortuosité de l'Espace Portal: Importance, Évaluation et Effets sur la Croissance Végétale. Ph.D. Thesis, Soil Science and Agrifood Engineering Department, Laval University, Sainte-Foy, QC, Canada, 1996.

10. Lynch, P. The 7 Stages of the Cannabis Plant Growth Cycle. In Way of Leaf. Available online: https://wayofleaf.com/cannabis/ growing/the-cannabis-plant-growth-cycle (accessed on 6 February 2021).

11. Franciosi, A. The 7 Key Stages of the Marijuana Plant Life Cycle. Honest Marijuana Company. Available online: https: //honestmarijuana.com/marijuana-plant/ (accessed on 24 April 2021).

12. Yafuso, E.J.; Fisher, P.R.; Bohorquez, A.C.; Altland, J.E. Water and air relations in propagation substrates. HortScience 2019, 54, 2024-2030. [CrossRef]

13. Huang, J.; Fisher, P.R. Quality control procedures in container growing substrates for young plant production. Acta Hort. 2014, 1034, 263-268. [CrossRef]

14. Haze, N. What's the Best Growing Medium: Soil, Coco or Hydro? Grow Weed Easy. Available online: https://www. growweedeasy.com/whats-the-best-cannabis-growing-medium (accessed on 10 February 2021).

15. Caron, J.; Nkongolo, V.K.N. Aeration in growing media: Recent developments. Acta Hort. 1999, 481, 545-551. [CrossRef] 
16. Bilderback, T.E.; Fonteno, W.C. Effects of container geometry and media physical properties on air and water volumes in containers. J. Environ. Hortic. 1987, 5, 180-182. [CrossRef]

17. Caplan, D.; Dixon, M.; Zheng, Y. Optimal rate of organic fertilizer during the vegetative-stage for cannabis grown in two coir-based substrates. HortScience 2017, 52, 1307-1312. [CrossRef]

18. Carlile, W.R.; Raviv, M.; Prasad, M. Organic soilless media components. In Soilless Culture Theory and Practice, 2nd ed.; Raviv, M., Lieth, J.H., Bar-Tal, A., Eds.; Elsevier: London, UK, 2019; pp. 303-378.

19. Blok, C.; Wever, G. Experience with selected physical methods to characterize the suitability of growing media for plant growth. Acta Hortic. 2008, 779, 239-249. [CrossRef]

20. Schmilewski, G. The role of peat in assuring the quality of growing media. Mires Peat 2008, 3, 1-8.

21. Jackson, B.E.; Fonteno, B.; Whipker, B.E. Your Complete Guide to Substrates in Cannabis Cultivation. Cannabis Business Times. Available online: https:/ / www.cannabisbusinesstimes.com/article/media-matters/ (accessed on 8 March 2021).

22. Barrett, G.E.; Alexander, P.D.; Robinson, J.S.; Bragg, N.C. Achieving environmentally sustainable growing media for soilless plant cultivation systems-A review. Sci. Hortic. 2016, 212, 220-234. [CrossRef]

23. White, B. Alternative Hydroponic Substrates. Greenhouse Product News. Available online: https://gpnmag.com/article/ alternative-hydroponic-substrates/ (accessed on 24 April 2021).

24. Maher, M.; Prasad, M.; Raviv, M. Organic soilless media components. In Soilless Culture Theory and Practice; Raviv, M., Lieth, J.H., Eds.; Elsevier: London, UK, 2008; pp. 459-504.

25. HortGrow. The Expert Way to Hydrate Coco Peat. Available online: https://hortgrow.com/blogs/blog/the-expert-wayto-hydrate-coco-peat\#: \{\}:text=It\%20takes\%20between\%204\%2D5,the\%20sides\%20of\%20the\%20block (accessed on 8 February 2021).

26. Poulter, R. Quantifying differences between treated and untreated coir substrate. Acta Hort. 2014, 1018, 557-564. [CrossRef]

27. Will, E.; Faust, J.E. Growing Media for Greenhouse Production. Agricultural Extension Service Univ. of Tennessee PB1618. 2010. Available online: https:/ / extension.tennessee.edu/publications/Documents/PB1618.pdf (accessed on 24 April 2021).

28. Smith, D.L. Rockwool in Horticulture; Grower Books: London, UK, 1987; 153p.

29. da Silva, F.F.; Wallach, R.; Chen, Y. Hydraulic properties of rockwool slabs used as substrates in horticulture. Acta Hort. 1995, 401, 71-75. [CrossRef]

30. Bussell, W.T.; Mckennie, S. Rockwool in horticulture, and its importance and sustainable use in New Zealand. N. Zealand J. Crop Hortic. Sci. 2004, 32, 29-37. [CrossRef]

31. Papadopoulos, A.P.; Bar-Tal, A.; Silber, A.; Saha, U.K.; Raviv, M. Inorganic and synthetic organic components of soilless culture and potting mixes. In Soilless Culture Theory and Practice; Raviv, M., Lieth, J.H., Eds.; Elsevier: London, UK, 2008 ; pp. 505-544.

32. OASIS®. Grower Solutions. Available online: https:// oasisgrowersolutions.com/hydropro/ (accessed on 5 February 2021).

33. Picken, P.; Reinikainen, O. Horticultural peat raw material and its physical characteristics in Finland, Sweden and the Baltics States. Acta Hort. 2009, 819, 125-134. [CrossRef]

34. Hähni, M.; Pouliot, R. Guide Pratique d'Identification des Plantes de Tourbières Ombrotrophes du Québec; APTHQ: Rivière-du-Loup, QC, Canada, 2011; 57p.

35. Vitt, D.H.; Slack, N.G. Niche diversification of Sphagnum relative to environmental factors in northern Minnesota peatlands. Can. J. Bot. 1984, 62, 1409-1430. [CrossRef]

36. Michel, J.C. The physical properties of peat: A key factor for modern growing media. Mires and Peat 2010, 6, 1-6.

37. Kandasamy, S.; Liu, E.Y.R.; Patterson, G.; Saldias, S.; Ali, S.; Lazarovits, G. Introducing key microbes from high productive soil transforms native soil microbial community of low productive soil. Microbiologyopen 2019, 8, e895. [CrossRef] [PubMed]

38. Raviv, M. Recent advances in soil-borne disease control using suppressive media. Acta Hort. 2009, 819, 125-134. [CrossRef]

39. Dorais, M. Organic greenhouse tomato production. In Achieving Sustainable Cultivation of Tomatoes; Mattoo, A., Handa, A., Eds.; Burleigh Dodds Science Publishing: London, UK, 2017; pp. 77-114. 